\section{Chemical Addition prior to Membrane Processes for Natural Organic Matter (NOM) Removal}

A.I. Schäfer, A.G Fane, T.D. Waite

\section{ABSTRACT}

Membrane processes for surface water treatment include microfiltration (MF), ultrafiltration (UF) and nanofiltration (NF), depending on the target material to be removed and the limiting process and naniltration (Nill , depending on the target material to be removed and the limiting process economics. MF will remove turbidity, but no dissolved compounds, unless associated with
colloids, UF will, depending on the molecular weight cut off (MWCO), partially remove NOM, and NF will remove NOM almost completely, but for a price often considered as uneconomic due to energy costs. Chemical addition prior to MF or UF may enhance the NOM removal capacity of these processes to a comparable range as achieved with NF. In this work the improvement of NOM removal by MF with chemical pretreatment was investigated using $\mathrm{FeCl}_{3}$ and hematite $\left(\alpha-\mathrm{Fe}_{2} \mathrm{O}_{3}\right)$ addition.

The results achieved with the addition of ferric chloride as a coagulant prior to MF showed that $95 \%$ removal of NOM can be achieved at a dosage of $25 \mathrm{mgL}^{-1}$. The flocs form a gelatina 95\% removal of $\mathrm{NO}$ membranes and cause flux compared to UF and NF. Higher dosage of $100 \mathrm{mgL}^{-1}$ resulted in a very high flux decline.

The addition of hematite synthesised as monodispersed, spherical colloids in the sizes 75, 250 and $500 \mathrm{~nm}$ showed the importance of colloid size on MF flux. Small colloids $(75 \mathrm{~nm})$ are not retained by the membrane when stabilised due to the adsorption of organics, but also adsorb larger amounts of NOM than do larger hematite particles. Aggregation of these colloids increased colloid rejection with a concomitant increase (to about $20 \%$ at a low dosage of $10 \mathrm{mgL}$ ${ }^{1}$ Hematite) in removal of adsorbed organic matter. Aggregation of small colloids increases the adsorbant surface area significantly versus larger primary colloids. The structure of the aggregates was found to be important for membrane flux.

Alternatively, tighter membranes can be used. UF membranes showed a NOM removal of 10 to $90 \%$ for a MWCO of 30 to $1 \mathrm{kDa}$ (five membranes were investigated), respectively. NF removed $>95 \%$ of organics, independent of solution che $>95 \%$ of organics, independent of solution chemistry and could remove a large fraction of
multivalent ions. The study shows that if no salt rejection (softening) but very high NOM removal $(>90 \%)$ are required in a water treatment application, hybrid processes of MF with chemical pretreatment may be a very attractive alternative to UF or NF.

\section{INTRODUCTION}

Natural water usually contains NOM, composed of hydrophobic (humic) and hydrophilic compounds, mono- and multivalent ions, low molecular weight organics, microorganisms, mixed complexes and inorganic colloids. NOM includes precursors of carcinogenic chlorination byproducts and its presence in drinking water thus presents a considerable (long-term) health risk. Chlorination is required to reduce the microbiological health risk after treatment and it is therefore necessary to remove NOM before chlorination to avoid by-product formation Conventional water treatment processes such as coagulation combined with sand filtration can remove NOM to a certain extent, however, enhanced coagulation (excess dosage of coagulant) is required to remove significant amounts of NOM (1), which increases both cost and environmental impact. Optimum turbidity removal may not be achieved under these conditions (2). The risk of filter breakthrough and the need for frequent maintenance are further drawbacks, especially in small communities. Membrane processes can overcome these drawbacks.
Membrane processes available for water treatment are microfiltration (MF), ultrafiltration (UF), nanofiltration (NF), and reverse osmosis (RO). All of these processes are pressure driven, with fluid passing through a "skin" which separates the solvent from the contaminant (solute). The removal capacity depends on the size of the pores of the membrane, as well as solute-membrane interactions. The removal of solute by membranes is dominated by two effects (i) size exclusion (steric hindrance, physical sieving), and (ii) charge interactions. Charge interactions are more significant when the solute is smaller that the pore size of the membrane. The pore sizes, operating pressure, removal and application capacity in municipal drinking water production of these processes are summarised in Table 1 . MF membranes have the largest pores and require therefore the lowest operating pressures, but cannot remove NOM, unless the NOM is (n) NOM is with chemical addition, such as coagulant or preformed colloids, can remove more NOM since the solute is associated with particles. Particulates and microorganisms will be removed by MF and the pretreatment can be optimised for optimum NOM removal (4). RO membranes are very tight and can retain very small solutes such as monovalent ions, but require a very high pressure to achieve a sufficient flux. The retention of monovalent ions is not normally required in the treatment of surface waters and RO is not considered in this study.

\section{EXPERIMENTAL METHODS}

Experiments were carried out in a perspex stirred cell (MF, UF; volume $110 \mathrm{~mL}, 270 \mathrm{rpm}$, membrane area $15.2 * 10^{-4} \mathrm{~m}^{2}$ ) and a stainless steel stirred cell (NF; volume $185 \mathrm{~mL}, 400 \mathrm{rpm}$, $21.2^{*} 10^{-4} \mathrm{~m}^{2}$ ). The operating pressures were 1,3 and 5 bar for MF (and some UF), UF, and NF, respectively. Details of membranes used are presented in Table 2; their selection was biased towards membranes exhibiting low organic adsorption characteristics. A new membrane was used for each experiment.

All chemicals were of analytical grade and supplied by Ajax Chemicals, Australia. MilliQ water was used for all experiments. Humic substances (Suwannee River Stream Reference humic acid (HA) and fulvic acid (FA)) were purchased from the International Humic Substances Society (HA) and USA and a d (IHSS, USA) and used to produce internationally comparable data. Australian NOM was concentrated from 5000L of raw water from Mooney Mooney Dam (NSW, Australia) using MF and RO prior to freeze drying (5). The characteristics of the organics are summarised in Table 3. Experiments were conducted at a temperature of $20 \pm 1^{\circ} \mathrm{C} .1 \mathrm{M} \mathrm{NaCl}, \mathrm{NaOH}$ and $\mathrm{HCl}$ were used for ionic strength and $\mathrm{pH}$ adjustment. All glassware used was soaked in $5 \mathrm{M} \mathrm{KOH}$ for $24 \mathrm{hrs}$ and then rinsed with MilliQ water to remove any organic contamination. The background solution consisted (if not indicated otherwise) of $0.5 \mathrm{mM} \mathrm{CaCl}_{2}, 1 \mathrm{mM} \mathrm{NaHCO}$ and $20 \mathrm{mM} \mathrm{NaCl}$. The relatively high background electrolyte was required to compensate for variations in solution chemistry. Ferric chloride $\left(\mathrm{FeCl}_{3}\right)$ and hematite $\left(\alpha-\mathrm{Fe}_{2} \mathrm{O}_{3}\right)$ were used for chemical pretreatment in these studies. $\mathrm{FeCl}_{3}$ was added from a $5 \mathrm{gL}^{-1}$ stock solution. Coagulation experiments were carried out with jar test equipment (stirring $100 \mathrm{rpm}$ for $2 \mathrm{~min}, 25 \mathrm{rpm}$ for $20 \mathrm{~min}$ ). Spherical, monodispersed hematite particles of a diameter of 75,250 , and $500 \mathrm{~nm}$ were used. The colloids were prepared in an identical manner to that described by Amal et al. (10), following the method of Matijevic and Schreiner (11)

A Varian Cary 1E Spectrophotometer was used to determine ultraviolet (UV) absorbance. A wavelength scan from 190 to $500 \mathrm{~nm}$ was performed for each sample. Total and dissolved organic carbon (TOC, DOC) was measured with a Skalar 12 TOC Analyser. D-Glucose was used as standard. A Perkin Elmer Optima 3000 Inductively Coupled Plasma Atomic Emission Spectroscopy (ICP-AES) instrument was used to determine the cation content of solutions. Samples were diluted with $1 \mathrm{M}$ nitric acid. All vials used were cleaned with $1 \mathrm{M}$ sulphuric acid. A Coulter Delsa 440 instrument was used to measure particle mobility, from which particle zeta potential was calculated. 
Schäfer, A.I. ; Fane, A.G · Waite, T.D. (1998) Chemical Addition prior to Membrane Processes for Natural Organic Matter (NOM) Removal,

\section{RESULTS AND DISCUSSION}

A comparative study of MF with various chemical pretreatment options with "tighter" membrane processes was carried out. This is the first comparative study of these processes using an identical feed solution.

\section{Microfiltration (MF)}

MF without pretreatment failed to remove either humic or fulvic acids, although some organic matter was lost to the clean membrane due to adsorption.

\section{Ferric Chloride Addition and Microfiltration (MF)}

Ferric chloride was chosen as the coagulant due to its higher efficiency to remove NOM and alkalinity compared to Alum (2). Ferric chloride added to an aqueous solution will start a continuous process of hydrolysis, complexation, polymerisation, solation, precipitation and gelation (12). The various species created will interact with other solution components such as particulates or NOM. Coagulation/flocculation can be driven by double layer compaction, charge neutralisation, bridging, entrapment into the precipitate (sweep flocculation) or adsorption onto the precipitate (2). The speciation depends strongly on the solution chemistry, $\mathrm{pH}$, ionic strength, buffer capacity, type of particulates and organics, and $\mathrm{FeCl}_{3}$ concentration. At a high coagulant dose (and high $\mathrm{pH}$ ), the dominant process of NOM removal is adsorption onto ferric hydroxide flocs and at low dosage (and low $\mathrm{pH}$ ), insoluble complexes such as humates or fulvates hydroxide flocs and at low dosage (and low pH

In this study, the $\mathrm{pH}$ after coagulant addition of about 4.5 corresponds to the optimum $\mathrm{pH}$ for NOM removal as shown in Figure 1. At these conditions, removal increases slowly with an increase in organic concentration (see Figure 2 (both sets of results for a ferric chloride concentration of $\left.25 \mathrm{mgL}^{-1}\right)$ ), indicating that the process is selective towards a fraction of NOM. The difference in removal for different organic types shows that hydrophobic compounds are preferentially removed. Since NOM contains a large portion of fulvic acid, its behaviour closely mimics that of the well-defined fulvic acid. The solubility of the humic acid is lower than that of the fulvic acid and interactions with colloids are stronger for the more hydrophobic humic acid (15)

At a lower dosage of $25 \mathrm{mgL}^{-1} \mathrm{FeCl}_{3}$ flocs are visible. These flocs were observed to break up during the filtration process. Higher dosages of $\mathrm{FeCl}^{-1}$ did not increase oranic matter removal, restabilstipe of the precipitate occurred at $100 \mathrm{mLL}^{-1} \mathrm{FeCl}$ a particulate load on the membrane, rejection remained high. Flux decline as a function of filtrate volume is shown for the various conditions examined in Figure $3 . \mathrm{J} / \mathrm{J}_{0}$ is the ration flux divided by filtrate flux at the start of filtration. MF with ferric chloride pretreatment increased NOM removal substantially. However, the process efficiency is very dependent on the nature of the organic matter, which is expected to change with origin (e.g. algal versus terrestrial), age, extent of oxidation. The MF removed substantially greater amounts of organics than could be achieved by settling, which showed that the removal is independent of the settlability of the flocs. Low dosages $\left(<25 \mathrm{mgL}^{-1} \mathrm{FeCl}_{3}\right)$ are sufficient to remove up to $90 \%$ humic acid. Flux decline was observed to be detrimental when coagulant was added to the solution prior to MF. However, the flux value corresponding to the flux ratio of 0.27 in Figure 3 is about $850 \mathrm{Lm}^{-2} \mathrm{~h}^{-1}$, which is significant Operaton at a lower 'controlled' flux of say $200 \mathrm{Lm}^{-2} \mathrm{~h}^{-1}$ should be sustainable without sig. The a a lowe 'con (n) cake more permeable. An electronmicrograph of the membrane deposit in the presence of $25 \mathrm{mgL} \mathrm{FeCl}_{3}^{-1}$
and $5 \mathrm{mgL}^{-1}$ DOC HA is shown in Figure $4 \mathrm{~A}$, an electronmicrograph of a deposit of $25 \mathrm{mgL}^{-1}$ $\mathrm{FeCl}_{3}, 10 \mathrm{mgL}^{-1}$ Hematite and $5 \mathrm{mgL}^{-1}$ DOC HA in Figure 4B.

Hematite Addition and Microfiltration (MF)
Chang and Benjamin (16) have added unheated and heated iron oxide particles to waters rich in NOM prior to UF. Flux decline was detrimental for the unheated particles and reduced with heating. It was assumed that the heated particles protect the membrane and increase NOM rejection due to adsorption. The mechanism of flux decline remains poorly understood.

Hematite of three different sizes $(72,250$, and $500 \mathrm{~nm}$ ) was chosen in this study and filtration behaviour was studied under various solution conditions. Stable colloids in the absence of organics showed a most serious flux decline when the primary particle size was close to the membrane pore size, thus for the $250 \mathrm{~nm}$ colloids (17). Identical results were obtained with colloids stabilised with organic matter (in this case colloids were mixed with organics prior to salt addition (OPS)), and ojection of the smll collo sols and testabilisation occurred and rejection increased. An electronmicrograph of the membrane deposit in the presence of $10 \mathrm{mgL}^{-1}$ Hematite and $5 \mathrm{mgL}^{-1} \mathrm{DOC} \mathrm{HA}$ is shown
in Figure $4 \mathrm{C}$. in Figure 4C.

Pore penetration and flux decline reached a maximum when the colloids were partially aggregated. Small colloids are required if NOM is to be removed by an adsorptive process due to the higher specific surface area of smaller colloids. To solve the problem of pore penetration and low rejection, the colloids were aggregated prior to adsorption (SPO). This resulted in full rejection of the colloids, but only minor rejection of organics (up to $20 \%$ ) was achieved with 10 $\mathrm{mgL}^{-1}$ Hematite. This is significantly less than with $25 \mathrm{mgL}^{-1} \mathrm{FeCl}_{3}$ which can be explained by the lower specific surface area of the aggregates versus stable colloids and ferric hydroxide flocs (see Table 4). Higher dosages will be required to achieve a similar removal.

The flux can be controlled by varying the aggregation regime of the colloids. At low salt The flux can be con the colloids. At low salt concentration, reaction limited aggregation (RLA) will take place, forming compact aggregates of a larger size. At high salt concentration the particle charge is screened by the ions (see Figure 5
for zeta potential), the colloids aggregate rapidly in the diffusion limited regime (DLA), forming for zeta potential), the colloids aggregate rapidly in the diffusion limited regime (DLA), forming
loose structures, which are prone to shear and remain smaller. The aggregate size distribution for loose structures, which are prone to shear and remain smaller. The aggregate size distribution for
three calcium chloride concentrations is shown in Figure 6; it is very similar for 2.5 and $4 \mathrm{mM}$ three calcium chloride concentrations is shown in Figure 6; it is very similar for 2.5 and $4 \mathrm{mM}$
$\mathrm{CaCl}_{2}$, when colloids have a close to neutral charge. Figure 7 shows the impact of calcium
concentration on membrane flux. Structure has a strong impact on flux, loose agregates form a concentration on membrane flux. Structure has a strong impact on flux, loose aggregates form a deposit with a higher permeability. The effect of particle size can be excluded, as the formed aggregates are larger at a lower calcium concentration, where the flux is lowest. The deposition of cake on the membrane is identical in mass for all calcium concentrations. NOM rejection is also identical $(17 \%)$. This observation is of great importance for the controlled formation of aggregates to remove NOM. The aggregates were stable and did not break during the filtration process, unless transmembrane pressures of $2-3$ bar were applied, which is well above the normally applied pressure of 0.5 to $1 \mathrm{bar}$.

\section{Ultrafiltration}

Fractionation experiments were carried out to evaluate the intrinsic rejection ability of the different membranes, all of identical material, but different molecular weight cut-offs (MWCO). The rejection results for the three different organics (as dissolved organic carbon (DOC)) are shown in Figure 8. The rejection of the membranes reflects the size of the molecules. The larger $\mathrm{HA}$ molecules are retained better than FA and NOM. Solution parameters such as $\mathrm{pH}$ and ionic strength, which influence the size of the organic molecules and membrane-solute interactions, did influence rejection.

Rejections of greater than $80 \%$ can be achieved with membranes of a MWCO smaller than 5 $\mathrm{kDa}$, however, the flux of these membranes is then of the same order as the NF flux where greater rejections can be obtained. The $100 \mathrm{kDa}$ membrane did not achieve NOM removal. 
Schäfer, A.I. ; Fane, A.G. ; Waite, T.D. (1998) Chemical Addition prior to Membrane Processes for Natural Organic Matter (NOM) Removal,

\section{Nanofiltration}

NF showed a high rejection of organics and a varying ion rejection depending on the membrane. Results for the smallest organic (FA) are summarised in Table 5. The TFC-ULP and TFC-S membranes remove most monovalent and multivalent cations, but their productivity also decreases $U / J_{w}$ is the ratio of flux after the experiment to pure water flux before the experiment). TFC-SR shows typical NF behaviour with a very interesting difference between multivalent and monovalent ion rejection. The CA-UF membrane does not have a high ion rejection and would thus be an ideal membrane for soft surface waters. Rejection of NOM was independent of the solution chemistry for the TFC membranes and the product quality does therefore not depend on the raw water quality.

\section{CONCLUSION}

Rejection of NOM (as DOC) for a range of membranes representing three different membrane processes have shown a decreasing rejection with initial pure water flux. MF did not remove NOM, but performance could be improved significantly (comparable to UF) with $\mathrm{FeCl}_{3}$ addition, especially for the larger molecular weight compounds (HA). Hematite addition can also improve NOM removal, however, higher dosages are required, but flux decline can be controlled better than with $\mathrm{FeCl}_{3}$ addition. The removal of NOM with MF and chemical pretreatment was dependent on the organic type and thus on variations in water quality.

"Tight" UF membranes achieved a rejection of over 80 percent at modest pressures (1 to $3 \mathrm{bar}$ ) NF showed a larger or similar rejection to tight UF membranes, at a higher flux and with optional softening (calcium removal), but at a higher pressure $(5 \mathrm{bar})$. NF performance towards rejection was independent of raw water quality. Figure 9 shows a comparison of results obtained for all processes as a function of initial pure water flux. It has to be noted that the initial pure water flux is a measure of membrane permeability and not the productivity after flux decline occurred.

The results presented show the ability of all three membrane processes to remove NOM and thereby produce a high quality drinking water. Membrane processes offer an ideal choice for the consumer; for example MF can be operated with chemical pretreatment when the NOM concentration is high or NF can be chosen if chemical addition is to be minimised or hard waters are to be treated.

\section{ACKNOWLEDGEMENTS}

The authors thank the Co-operative Research Centre for Water Quality and Treatment (CRC WQ\&T) for project funding. M.M. Fischer, R. Mauch, U. Schwicker and N. Sugiharto are acknowledged for experimental work. The assistance of P. Marks (Electronmicroscope Unit, UNSW) with specimen preparation is appreciated. Millipore (Australia) is thanked for material support and Fluid Systems (San Diego, U.S.) for the supply of membrane samples.

\section{REFERENCES}

(1) Crozes,G., Jacangelo, J., Anselme, C., Laîné, J.M.: Impact of Ultrafiltration Operating Conditions on Membrane Conference, Reno, Nevada (1995) 457

(2) Crozes, G. White, P. Marchall, M. Enhanced coagulation its effect on NOM removal and chemical costs. (2) Crozes, G., White, 1995$) 78$ (3) Mallevialle, J., Odendaal, P.E., Wiesner, M.R.: Water Treatment Membrane Processes, 1996, McGraw-Hill (4) Vickers, J.C., Thompson, M.A., Kelkar, U.G.: The use of membrane filtration in conjunction with coagulation processes for improved NOM removal. Desalination 102 (1995) 57

( 5 ) Schäfer, A.I., Fane, A.G., Waite, A.G.: A Review on the Options for Removal of Natural Organics by Membranes, Proc. International Membrane Science and Technology Conference Sydney 2 (1996) 7 (6) Jucker, C., Clark, M.M.: Adsorption of Aquatic Humic Substances on Hydrophobic Ultrafiltration Membranes,

(7) Beckett, R., Jue, Z., Giddings, J.C.: Determination of Molecular Weight Distribution of Fulvic and Humic Acids (7) Beckett, R., Jue, Z., Giddings, J.C.: Determination of Molecular Weight Distribution of Fu
Using Flow Field-Flow Fractionation. Environmental Science \& Technology 21/3 (1987) 289

( 8 ) Hering, J.G., Morel, F.M.M. Humic Acid Complexation of Calcium and Copper, Environent Science \& Technology 22/10 (1988) 1234

( 9 ) Schäfer, A.I., Mauch, R., Hepplewhite, C., Fane, A.G., Waite, T.D.: Charge Effects in the Fractionation of Humic Substances and Natural Organic Matter using Ultrafiltration. (in preparation)

(10) Amal, R., Raper, J.A., Waite, T.D.: Effect of Fulvic Acid Adsorption on the Aggregation Kinetics and Structure of Hematite Particles. Journal of Colloid and Interface Science 151/1 (1992) 244

(11) Matijevic, E., Schreiner, P.: Ferric Hydrous Oxide Sols III. Preparation of Uniform Particles by Hydrolysis of Fe(III)-Chloride, -Nitrate, and -Perchlorate Solutions, Journal of Colloid and Interface Science 63/3 (1978) 509

(12 Tang, H.X., Tian B.Z., Luan, Z.K., Zhang, Y.. Hnorganic Polymer Hocculant Bolyferric Chloride, lt's

(Eds.). Springer, Berlin, Heidelberg 1994, pp. 57-69.

(13) Krasner, S.W., Amy, G.: Jar testing evaluations of enhanced coagulation. Journal AWWA 10/95 (1995) 93 (14) Dennett, K.E., Amirtharajah, A., Moran T.F., Gould J.P.: Coagulation: its effect on organic matter. Journal AWWA, 04/96 (1996) 129

(15) Gu, B., Schmitt, J., Chen, Z., Liang, L., McCarthy, J.F.: Adsorption and Deposition of Natural Organic Matter in Iron Oxide: Mechanisms and Models. Environmental Science \& Technology 28/1 (1994) 38

(16) Chang, Y., Benjamin, M.M. Iron oxide adsorption and UF to remove NOM and control fouling. Journal

17 Schafer, A.I., Fischer, M.M., Schwicker, U., Fane, A.G., Waite, T.D.: Physicochemical Aspects on (18) Croso, S A Glosson, D R Cutter, AH, Buter, I, Th

Turner, D.R., Whitfield, M., Millward, G.E.: Surface 709

A.I. Schäfer, Prof. A.G. Fane

UNESCO Centre for Membrane Science and Technology

School of Chemical Engineering and Industria Chemistry

University of New South Wales

Sydney NSW 2052

Australia
Prof. T.D. Waite

Department of Water Engineering School of Civil and Environmental Engineering University of New South Wales Sydney NSW 2052

Australi 
Schäfer, A.I. ; Fane, A.G. ; Waite, T.D. (1998) Chemical Addition prior to Membrane Processes for Natural Organic Matter (NOM) Removal,

in: Chemical Water and Wastewater Treatment V, H.H. Hahn, E. Hoffman, H. Ødegaard (Eds.), Springer, 8th International Gothenburg Symposium, Prague, Sept 1998, $125-137$.

\section{TABLE}

Table $1 \quad$ Overview of membrane processes in water treatment (3)

\begin{tabular}{|c|c|c|c|c|}
\hline Process & $\begin{array}{c}\text { Pore Size } \\
{[\mathrm{nm}]}\end{array}$ & $\begin{array}{l}\text { Operating } \\
\text { Pressure } \\
\text { [bar] }\end{array}$ & Removal Achieved & $\begin{array}{c}\text { Municipal Drinking } \\
\text { Water Production (1994) } \\
{\left[\mathrm{m}^{3} / \mathrm{d}\right]}\end{array}$ \\
\hline MF & macropores & $0.3-3$ & turbidity & 31000 \\
\hline UF & $\begin{array}{c}>50 \mathrm{~nm}(100 \mathrm{~nm}) \\
\text { mesopores } 2-50 \\
\mathrm{~nm}(10 \mathrm{~nm})\end{array}$ & $0.5-7$ & turbidity and macromolecule & 63000 \\
\hline NF & $\begin{array}{l}\text { micropores } \\
<2 \mathrm{~nm}\end{array}$ & $3.5-10$ & $\begin{array}{l}\text { high hardness and organics } \\
\text { (surface \& ground water) }\end{array}$ & 500000 \\
\hline RO & non-porous (?) & $8-80$ & salt (sea- and brackish water) & 3000000 \\
\hline
\end{tabular}

Table 2 porous (?)
Table 5 Rejection and flux ( $5 \mathrm{moL}^{-1}$ oronic carbon $\mathrm{FA}, 0.5 \mathrm{mM} \mathrm{CaCl}, 1 \mathrm{mM} \mathrm{NaHCO}$ $20 \mathrm{mM} \mathrm{NaCl}$ ). The three values present samples after 40,80 and $120 \mathrm{~mL}$ filtration, respectively.

\begin{tabular}{|c|c|c|c|c|c|c|}
\hline Membrane & $\begin{array}{c}\mathrm{pH} \\
{[-]}\end{array}$ & $\begin{array}{c}\text { DOC Rejection } \\
{[\%]}\end{array}$ & $\begin{array}{c}\text { UV } 254 \mathrm{~nm} \\
\text { Rejection [\%] }\end{array}$ & $\begin{array}{c}\mathrm{Ca}^{2+} \\
\text { Rejection [\%] }\end{array}$ & $\begin{array}{c}\mathrm{Na}^{+} \\
\text {Rejection [\%] }\end{array}$ & $\begin{array}{c}\mathrm{J} / \mathrm{Jw}_{\mathrm{w}} \\
{[-]}\end{array}$ \\
\hline $\begin{array}{l}\text { TFC-ULP } \\
\text { TF }\end{array}$ & 8 & $72 / 83 / 86$ & $80 / 91 / 93$ & $87 / 92 / 92$ & $83 / 87 / 85$ & 0.37 \\
\hline TFC-S & 8 & $78 / 83 / 90$ & $93 / 95 / 96$ & $92 / 95 / 96$ & $74 / 85 / 87$ & 0.63 \\
\hline TFC-SR & 8 & $94 / 94 / 94$ & $94 / 96 / 98$ & $67 / 68 / 68$ & $34 / 40 / 38$ & 0.91 \\
\hline CA-UF & 8 & $68 / 72 / 72$ & $76 / 88 / 85$ & $17 / 13 / 13$ & $17 / 11 / 10$ & 1.11 \\
\hline
\end{tabular}

\begin{tabular}{ccccccc}
\hline Process & Supplier & Type & $\begin{array}{c}\text { Pressure } \\
{[\mathrm{bar}]}\end{array}$ & $\begin{array}{c}\text { Specifications } \\
\text { Pore Size }[\mu \mathrm{m}] \\
\text { Molecular Weight } \\
\text { Cut-Off }[\mathrm{kDa}]\end{array}$ & $\begin{array}{c}\text { Pure Water } \\
\text { Flux } \\
{\left[\mathrm{Lm}^{-2} \mathrm{~h}^{-1}\right]}\end{array}$ & $\begin{array}{c}\text { Surface } \\
\text { Charge at } \\
\mathrm{pH} 8 \\
{[\mathrm{mV}]}\end{array}$ \\
\hline MF & Millipore & GVWWP & 1 & $0.22 \mu \mathrm{m}$ & $7970 \pm 290$ & -21.1 \\
& & GVHP & 1 & $0.22 \mu \mathrm{m}$ & $8090 \pm 320$ & -9.8 \\
UF & Millipore & PLHK & 1 & $100 \mathrm{kDa}$ & $1320 \pm 40$ & -17.3 \\
& & PLTK & 1 & $30 \mathrm{kDa}$ & $390 \pm 20$ & -16.4 \\
& & PLGC & 3 & $10 \mathrm{kDa}$ & $65 \pm 5$ & -7.5 \\
& & PLCC & 3 & $5 \mathrm{kDa}$ & $28 \pm 3$ & -14.3 \\
& & PLBC & 3 & $3 \mathrm{kDa}$ & $22 \pm 2$ & -9.2 \\
NF & FLAC & 3 & $1 \mathrm{kDa}$ & $15 \pm 2$ & -11.6 \\
& Fluid & PLA-UF & 5 & - & $50 \pm 4$ & -11.0 \\
& Systems & TFC-SR & 5 & - & $46 \pm 6$ & -21.8 \\
& & TFC-S & 5 & - & $49 \pm 6$ & -6.5 \\
& & TFC-ULP & 5 & - & $19 \pm 3$ & -19.4 \\
\hline
\end{tabular}

Table 3 Acidity and average molecular weight of the organics $\left({ }^{1}(6),{ }^{2}(7),{ }^{3}(8),{ }^{4}(9)\right)$

Type of Organic Acidity [meq..$\left.^{-1}\right] \quad$ Average Molecular Weight $[\mathrm{kDa}]$

$\begin{array}{lccc} & \text { Carboxylic } & \text { Phenolic } & \\ \text { IHSS FA } & 3.4^{1} & 1.5^{1} & 750^{2}\end{array}$

\begin{tabular}{llllll} 
IHSS FA & $3.4^{1}$ & $1.5^{1}$ & & $750^{2}$ & \\
IHSS HA & $4.0^{1}$ & $2.9^{1}$ & $1100^{3}$ & $1500^{2}$ & $1200^{4}$ \\
\hline
\end{tabular}

$\begin{array}{llll}\text { Mooney Mooney NOM } & 5.1^{4} & 1.3^{4} & <1000^{4}\end{array}$

Table $4 \quad$ Specific surface area of iron particles for chemical pretreatment

\begin{tabular}{cc}
\hline \multicolumn{1}{c}{ Type of Iron Particle } & Specific Surface Area $\left[\mathrm{m}^{2} \mathrm{~g}^{-1}\right]$ \\
\hline $\mathrm{FeCl} 3$ Floc & $160-230^{(18)}$ \\
$75 \mathrm{~nm}$ Hematite & $151^{*}$ \\
$250 \mathrm{~nm}$ Hematite & $45^{*}$ \\
$500 \mathrm{~nm}$ Hematite & $23^{*}$ \\
\hline
\end{tabular}

* calculated on the basis of spherical particles of a density of $5.24 \mathrm{~g} . \mathrm{cm}^{-3}$ 
Schäfer, A.I. ; Fane, A.G. · Waite, T.D. (1998) Chemical Addition prior to Membrane Processes for Natural Organic Matter (NOM) Removal,

in: Chemical Water and Wastewater Treatment V, H.H. Hahn, E. Hoffman, H. Ødegaard (Eds.), Springer, 8th International Gothenburg Symposium, Prague, Sept 1998, $125-137$.

\section{FIGURES}

Figure 1 TOC rejection as a function of feed $\mathrm{pH}$ for the three different types of organics $\left(25 \mathrm{mgL}^{-1} \mathrm{FeCl}_{3}, 5 \mathrm{mgL}^{-1}\right.$ organic carbon)

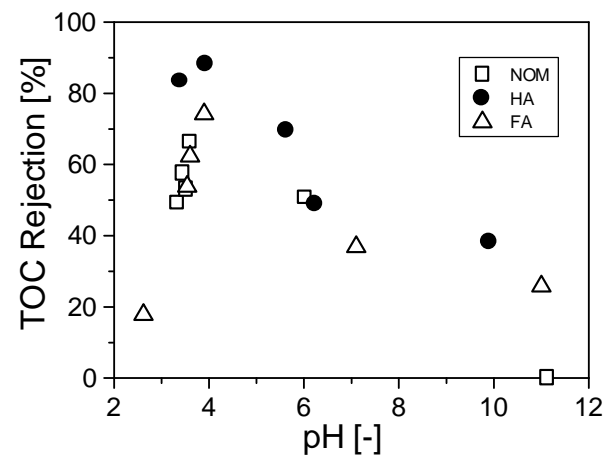

Figure 2 TOC rejection as a function of feed organic concentration for the three different types of organics $\left(25 \mathrm{mgL}^{-1} \mathrm{FeCl}_{3}, \mathrm{pH} 4.5\right)$

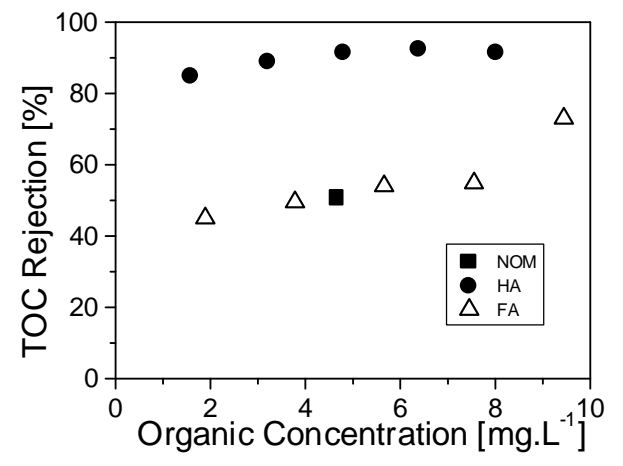

Figure 3 Microfiltration flux ratio over filtrate volume after jar tests with solutions containing $5 \mathrm{mgL}^{-1}$ dissolved organic carbon (HA)

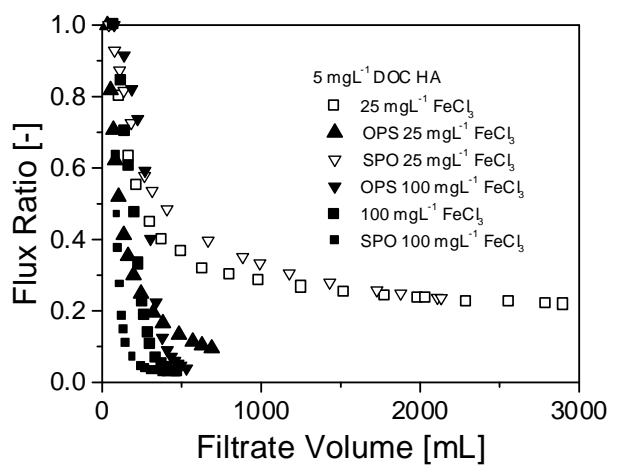


Schäfer, A.I. : Fane, A.G. · Waite, T.D. (1998) Chemical Addition prior to Membrane Processes for Natural Organic Matter (NOM) Removal,

in: Chemical Water and Wastewater Treatment V, H.H. Hahn, E. Hoffman, H. Ødegaard (Eds.), Springer, 8th International Gothenburg Symposium, Prague, Sept 1998, $125-137$.

Figure 4 Electronmicrograph of membrane deposit after filtration of a solution containing (A) $25 \mathrm{mgL}^{-1} \mathrm{FeCl}_{3}, 5 \mathrm{mgL}^{-1}$ DOC humic acid, (B) $25 \mathrm{mgL}^{-1} \mathrm{FeCl}_{3}, 5 \mathrm{mgL}^{-1}$ DOC humic acid and $10 \mathrm{mgL}^{-1}$ Hematite aggregates and (C) $5 \mathrm{mgL}^{-1}$ DOC humic acid and $10 \mathrm{mgL}^{-1}$ Hematite aggregates
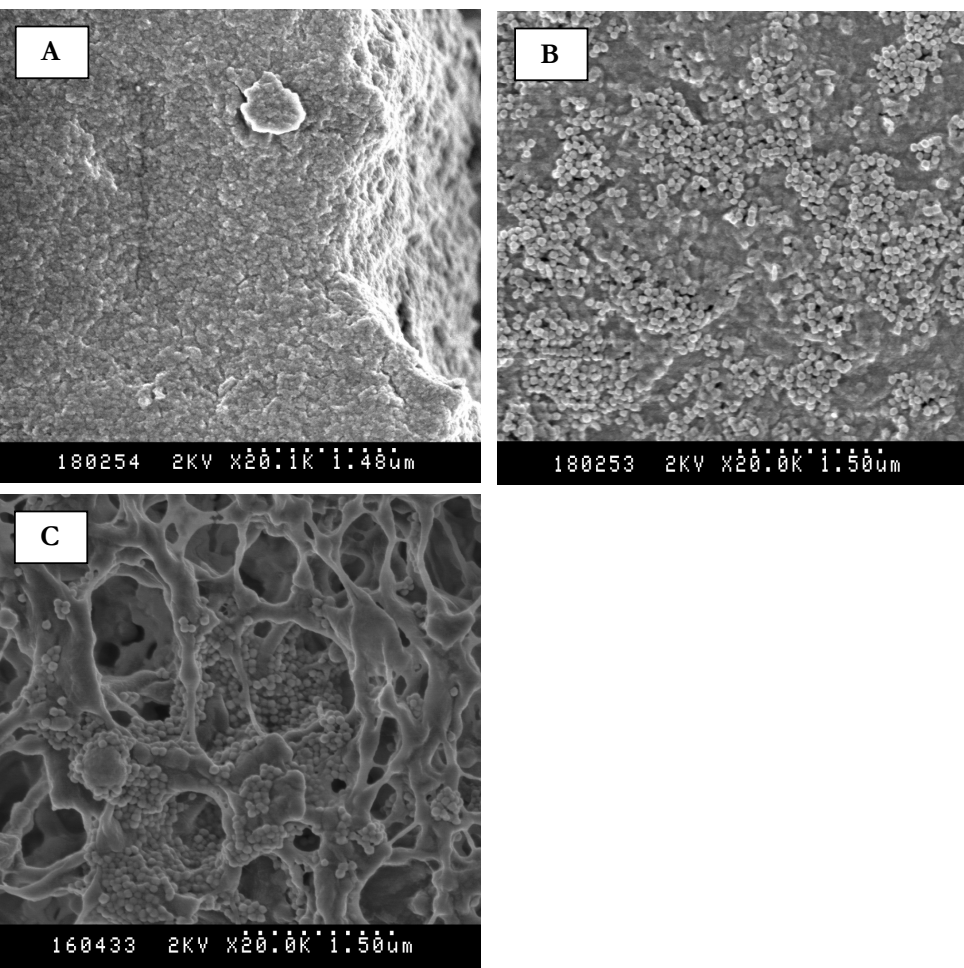

Figure 5 Zeta potential of hematite aggregates (primary particle size $75 \mathrm{~nm}$ ) as a function of calcium chloride concentration

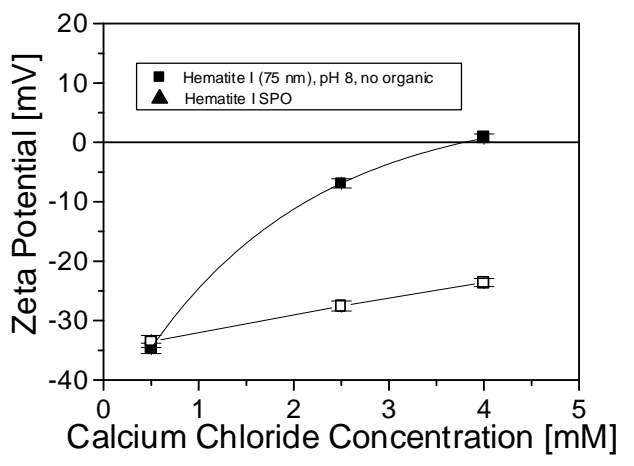

Figure 6 Size Distribution of Hematite Aggregates (primary particle size $75 \mathrm{~nm}$ ) at various calcium chloride concentrations

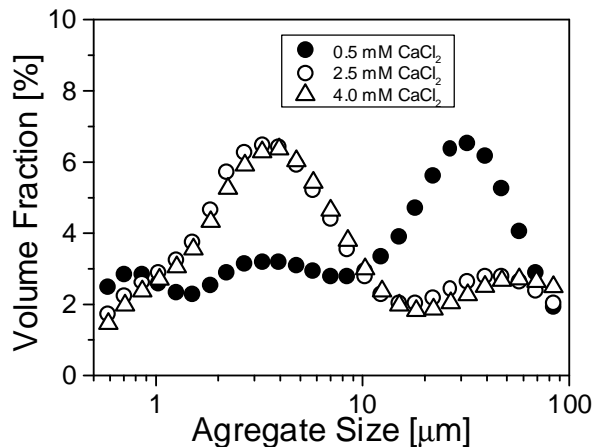


Schäfer, A.I. ; Fane, A.G · Waite, T.D. (1998) Chemical Addition prior to Membrane Processes for Natural Organic Matter (NOM) Removal,

in: Chemical Water and Wastewater Treatment V, H.H. Hahn, E. Hoffman, H. Ødegaard (Eds.), Springer, 8th International Gothenburg Symposium, Prague, Sept 1998, $125-137$.

Figure 7 Flux over filtrate volume for aggregates at various calcium concentrations

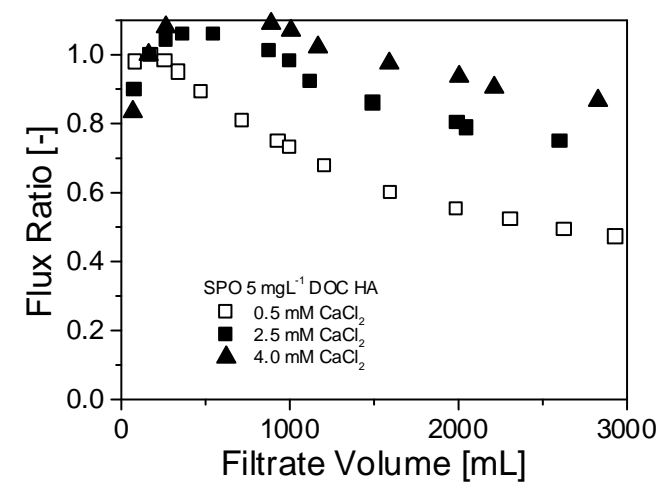

Figure 8 Rejection of various UF membranes of the different types of NOM and HS (15 $\mathrm{mgL}^{-1}$ organic carbon)

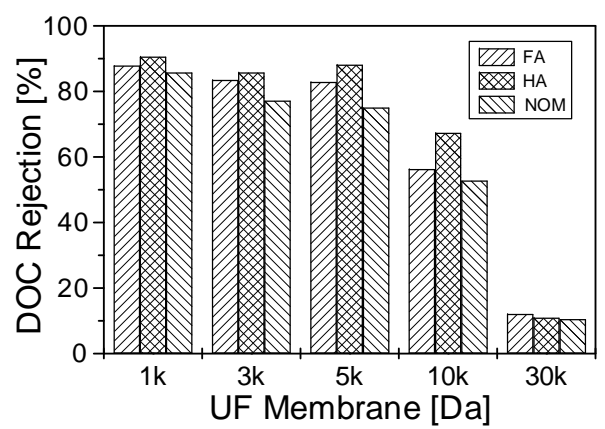

Figure 9 Rejection of DOC as a function of membrane pure water flux for the three membrane processes and MF with coagulation pretreatment

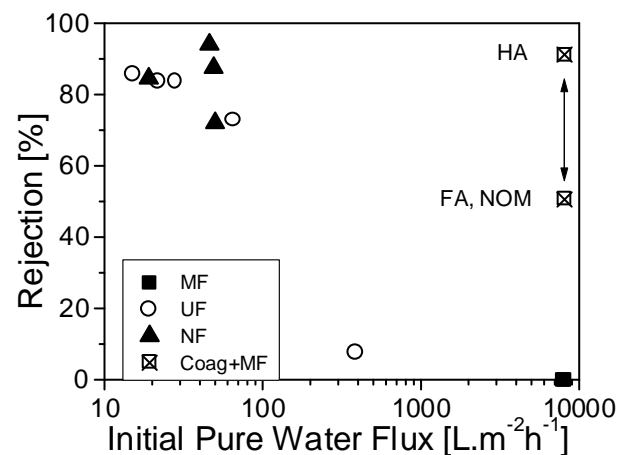

